\title{
GRADUATION OF A SOLID MATERIAL GROUND BY A CAVITATION PULSE TECHNOLOGY
}

\author{
Institute of Technical Mechanics \\ of the National Academy of Sciences of U kraine and the State Space Agency of U kraine, \\ 15 Leshko-Popel St., D nipro 49005, U kraine; e-mail: Poffice.itm@ nas.gov.ua
}

\begin{abstract}
A technology was developed at the Institute of Technical Mechanics of the National Academy of Sciences of Ukraine and the State Space Agency of Ukraine for the production of solid-water fine-dispersed media by cavitation pulse processing of solids. A prompt and reliable analysis of the effect of the operating conditions of the cavitation pulse plant and its design parameters on the efficiency of solid particle grinding and the particle size is a topical problem. The aim of this paper is to analyze possible ways and methods for prompt particle size determination, to choose the most convenient method to be used in laboratory conditions, and to adapt it to the study of the cavitation pulse technology.

Powder substances and mixtures thereof are in ever-increasing use in metallurgy, medicine, the paint and varnish industry, etc. The growing competition among manufactures of various products places more and more stringent requirements on the stability of their production and thus on the reliability of data on the characteristics of their components. Concurrent with the toughening of the requirements for the composition of fine-dispersed materials, the requirements for the promptitude of its determination become more stringent too. This is also true for the component grain-size composition. The grain-size composition of powders is the most important and often decisive factor of the way they perform in use. This paper presents a new technology of application of the sieve method to mixture composition determination. The technology is simple and reliable, needs a minimum of personnel skill, and is sufficiently accurate. Besides, two types of grain-size composition may be specified: by the product mass that has remained on the sieve and by the product mass that has passed through the sieve.
\end{abstract}

Keywords grain-size analysis, conductometric analysis, sedimentation analysis, laser scanning method, sieve analysis, sieves.

1. Appelt G. Introduction to Microscopic Examination Methods. Moscow, Medgiz, 1959. 429 pp. (in Russian).

2. Samoilenko S. O., Hubskyi S. M. Modern Methods for Raw Material and Food Analysis. Lectures. Kharkiv: Kharkiv State University of Food Technology and Trade, 2019. 73 pp. (in Ukrainian).

3. Smyrnov V. O., Serhieiev P.V., Biletskyi V. S. Coal Preparation Technology. Manual. Donetsk: Eastern Publishing House, 2011. 476 pp. (in Ukrainian).

4. Naumov S. V. Modern methods for the graduation of welding material powder components. Bulletin PNRPU. Mechanical Engineering, Materials Science. 2012. 7 pp. URL:

https://cyberleninka.ru/article/n/sovremennye-metody-opredeleniya-granulometricheskogo-sostavaporoshkoobraznyh-komponentov-svarochnyh-materialov/viewer. (in Russian).

5. Volkov V. Colloid Chemistry. Surface Phenomena and Disperse Systems. Lan Publishers, 2012. 672 pp. (in Russian).

Received on June 2, 2020, in final form on June 26, 2020 